\title{
Toll-like receptors and skin cancer
}

\section{Erin M. Burns and Nabiha Yusuf*}

Department of Dermatology, University of Alabama at Birmingham, Birmingham, AL, USA

*Correspondence: nabiha@uab.edu

Edited and reviewed by:

Christophe M. Filippi, Genomics Institute of the Novartis Research Foundation, USA

Keywords: Toll-like receptor, non-melanoma skin cancer, BCC, SCC, melanoma, innate immunity

The skin, the largest organ in the body, provides the first line of defense against the environment both as a physical barrier and as a key immunological component. Toll-like receptors (TLRs) serve as signaling molecules that recognize pathogenassociated molecular patterns (PAMPs) as well as damage-associated molecular patterns (DAMPs), and are expressed by various skin cells including keratinocytes and melanocytes, which are the main cell types involved in both non-melanoma and melanoma skin cancers. TLRs induce inflammatory responses meant for clearing pathogens, but can ultimately contribute to skin carcinogenesis. In contrast, TLR agonists, specifically targeting TLR7, 8 , and 9 , have been successfully used as therapeutics for melanoma and basal cell carcinoma (BCC), functioning by recruiting dendritic cells and inducing T-cell responses. Here, we discuss the role TLRs play in skin carcinogenesis as well as the use of TLRs as targets for skin cancer treatment options.

\section{SKIN AND TLRs}

Non-melanoma skin cancer (NMSC) includes BCC and squamous cell carcinoma (SCC). With over 3.5 million new diagnoses annually, NMSC is the most common cancer in the United States (1). Risk factors for developing NMSC include ultraviolet (UV) light exposure, skin color, sunburns, age, and immunosuppressive status (2). NMSCs account for over 3,000 deaths each year (3) and also contribute to over $\$ 1.4$ billion annually for the treatment and management of these skin tumors (4). Melanoma contributes to approximately $5 \%$ of all skin cancer diagnoses, with 76,000 new cases diagnosed in 2012 (5). Importantly, melanoma leads to over 9,000 deaths annually, which accounts for the majority of skin cancer deaths. Risk factors for melanoma include UV exposure, sunburn, nevi, immunosuppressive status, and family history.

The most common treatments for SCC include excision, Mohs micrographic surgery, and cryosurgery, which, when the lesion is detected early and promptly removed, are effective and cause minimal damage (2). If left untreated, the tumors are able to grow exponentially or metastasize, leading to more invasive procedures. For melanoma, surgical excision is the most common treatment, with recent preferences for Mohs surgery (5). However, in the case of recurring lesions or lesion patches, surgery may not be an option due to extensively damaged skin or lack of tissue for removing clear margins, resulting in the need for alternative treatment options.

The skin is the largest organ in the body and contains three major cell types, which include melanocytes, Langerhans cells, and keratinocytes. Keratinocytes are the major cell type of the epidermis and provide defense against the environment both as a physical barrier and a key component of the innate immune response $(6,7)$. Epidermal keratinocytes, as the outmost environmental barrier, are responsible for the production of antimicrobial peptides (8), which are up-regulated by various stimuli through both the mitogen-activated protein (MAP) kinase and nuclear factor (NF) kappaB pathways (9). TLRs are expressed by various skin cells including keratinocytes and melanocytes (10), which are the main cell types involved in both non-melanoma and melanoma skin cancers. Human keratinocytes have been shown to express TLRs $1-6$ and 9 (10-14). Recently, it has been reported that TLR2-5, 7,9 , and 10 are constitutively expressed in human melanocytes (15).

Toll-like receptors serve as signaling molecules that recognize PAMPs, or pathogen-associated molecular patterns, as well as DAMPs and thus, activate the innate immune response through the transcription factor NF-kB (16). The 10 human TLR family members are characterized by the leucine-rich repeat domain content in both their extracellular region and the intracellular Toll-IL-1 receptor (TIR) domain (17), which can therefore interact with adaptor molecules that contain appropriate adaptor molecules (18).

Toll-like receptors have been demonstrated to be important for both innate immune response specificity $(19,20)$ as well as for adaptive immune responses such as dendritic cell maturation and costimulatory molecule expression and the promotion of Th-1 cell-mediated responses through increased production of IL-12 by activated TLRs on dendritic cells $(21,22)$. It also has been reported that innate inflammatory responses localized to the epidermis may be affected by TLR expression in human melanocytes (23). TLRs are activated in melanocytes, as a consequence of the inflammatory response to tissue injury, sunburn or skin infection, and constitute a natural defense to recruit innate immune cells.

\section{TLR STIMULATION AND SKIN CARCINOGENESIS}

Besides their function of recognizing exogenous PAMPs, TLRs also recognize endogenous ligands, which are often referred to as alarmins and function to recognize cell or tissue damage and alert the innate and adaptive immune systems $(24,25)$. Expression association studies have revealed potential functions of TLR endogenous ligands in tumorigenesis. For example, high-mobility group box-1 protein (HMGB1) can function as a DAMP and is released in response to tissue or cellular damage. It is over-expressed in several human neoplasms including lung, pancreatic, breast, liver, and colorectal cancers, 
and, importantly, melanoma (26). HMGB1 is either passively released by injured or necrotic cells (27) or actively secreted by monocyte/macrophages, neutrophils, and dendritic cells [reviewed in Ref. (28)].

With the exception of TLR3 that signals through Toll/IL-1R domain containing adaptor inducing IFN (TRIF), TLRs signal through myeloid differentiation factor 88 (MyD88). TLR signaling has been reviewed extensively elsewhere (29). MyD88 is an adaptor protein that is ultimately responsible for initiating NF-kB activation (30), and therefore the amplification of inflammation and the promotion of tumor development (31). Importantly, chronic inflammation has been linked to tumor development in animal models of both spontaneous and chemically induced carcinogenesis $(32,33)$.

Tumor cells expressing TLRs may be able to evade immune surveillance processes, thus promoting tumor development. The activation of TLR4 and subsequent signaling molecules have been shown to upregulate immunosuppressive cytokines such as IL-10 as well as proinflammatory cytokines and chemokines including IL-6, IL-18, and TNF- $\alpha$, which have been shown to contribute to tumor development, growth, and even metastasis (34). In human melanoma A375 cells, the inhibition of TLR4/MyD88 signaling effectively decreased both VEGF and IL-8 levels with paclitaxel and icariside II combination treatment (35). TLR2-4 are expressed and up-regulated in several human metastatic melanoma cell lines (36), with recent data indicating that melanoma cells also express TLR7, 8, and 9 (37), which are abnormally upregulated in cells from melanoma biopsies (38). The over-expression of TLR4 within melanoma tumors triggers an inflammatory response leading to tumor development (39). TLR9 activation has also been shown to enhance invasion as well as promote proliferation in several cancer cell lines via NF-kB and Cox-2 activation (40), as well as the secretion of IL- 8 and IL- $1 \alpha$ (41), and TGF- $\beta$ (42). Recent studies in head and neck cancer have revealed that TLR 3 expression and signaling affects the migration and metastatic potential of tumors as evidenced in oral SCC by inducing CCL5 and IL- 6 secretion (43).
Importantly, TLR inhibition can exert anti-cancer effects. TLR4 pathway inhibition reversed tumor-mediated suppression of both natural killer cell activity as well as T-cell proliferation in vitro and in vivo, resulting in increased tumor latency and survival of tumor-bearing mice (44). TLR2 plays an important role in the induction of tumor regression, which has been demonstrated in a mouse model of glioblastoma multiforme where blocking HMGB1-mediated TLR2 signaling via tumor-infiltrating myeloid DCs resulted in a loss of therapeutic efficacy (45).

TLR3 activation on immune cells results in anti-cancer activities, where $\mathrm{T}$ cellmediated responses are promoted (46). Specifically, upon stimulation with TLR3 agonist poly(I:C), CD8 T cell responses are enhanced, leading to the production of IFN $\gamma$ and TNF- $\alpha$ and ultimately, the generation of memory CD8 T cells.

\section{TLR-TARGETED THERAPY}

Although TLR expression on tumor cells may allow tumors to evade surveillance, TLRs are also considered to be targets for anti-cancer interventions that result in the recognition and ultimate destruction of tumor cells using a tolerant immune system. This idea is further illustrated by the fact that recent studies have demonstrated a dual nature of immune responses in the context of cancer therapies, highlighting the importance of considering conditions, TLR targets, and combinations of immune interventions and TLR ligands (47).

There are studies and case reports that show that $5 \%$ imiquimod cream treatment is an effective therapeutic option for actinic keratosis (AK), BCC, Bowen's disease, and lentigo maligna (48-53). The mechanism of action of imiquimod is through the activation of TLR7 (54), and imiquimod has been approved to treat both premalignant actinic keratoses, and malignant superficial BCC (55). The mechanism may also involve Th1-response promotion, the recruitment of macrophages, anti-tumor cytotoxic CD8 T cells, and NK cells to the lesion, as well as induce apoptosis of tumor cells $(55,56)$. Imiquimod has also been shown to induce IFN- $\alpha$ and IL-12 production, resulting in a heightened immune response $(49,57,58)$. The suggested mechanism for exertion of anti-tumor effects on UVB-induced SCC by imiquimod is through the activation of Th17/Th1 cells as well as cytotoxic $\mathrm{T}$ lymphocytes (59). Five percent topical imiquimod has been effective in several clinical trials $(49,53,57$, 60 ). The related drug, resiquimod, has been demonstrated as a safe and effective topical intervention for $\mathrm{AK}$ and is a potential treatment option for patients who have large patches of AK (61).

Several cancer types including melanoma have been successfully treated with Taxol, CpG, or otherTLR ligands (62, 63). PF3512676, a synthetic CpG ODN, uses a TLR9-targeted approach to effectively treat BCC (64). TLR 7 and 8 agonists activate a pro-inflammatory response for SCC treatment (65). Additionally, IL-1, 6,8 , and 12 modulation along with a promotion of a Th1-response have been shown to exert anti-tumor and antiviral behavior (65).

Previous studies have demonstrated TLR3 agonists to be promising adjuvants for cancer vaccines, especially in regards to their immunostimulatory properties (46). A recent study has demonstrated that human melanoma cells express TLR3, which in combination with TLR3 agonists, results in tumor cell death via caspase activation when cells are pretreated with cycloheximide or IFN- $\alpha$ (38), suggesting that TLR3 agonists may be multifunctional adjuvants offering more clinical treatment options. Therefore, TLRs and their signaling pathways may be potential therapeutic targets to control tumor progression, especially in diseases such as cutaneous malignant melanoma, which is an aggressive tumor that is not effectively managed with current treatments (66).

It is important to note that, especially in the case of TLR7 agonists such as imiquimod and resiquimod, though quite effective when applied topically to AKs and BCCs, systemic therapeutic interventions have not been as successful. This TLR tolerance has previously been demonstrated with TLR4 agonists, which resulted in decreased NF-kB activation (67). The suggested mechanism for TLR7 tolerance is the diminished capacity for IL-12 secretion as well as IFN- $\alpha$ secretion by plasmacytoid DCs (68). Recent studies have found that local and systemic TLR-targeted therapies have different modes of action and require further investigation, especially into the timing and dosage of treatments to reach 
maximum efficacy without inducing TLR tolerance (69).

\section{CONCLUSION}

In summary, TLRs are an important immunological component expressed by keratinocytes and melanocytes, which are the main cell types involved in both non-melanoma and melanoma skin cancers. TLRs induce inflammatory responses meant for clearing pathogens, but their activation can also potentiate chronic inflammation, which can ultimately contribute to skin carcinogenesis. In contrast, TLR agonists, specifically targeting TLR7, 8 , and 9 , have been successfully used as therapeutics for melanoma and BCC, functioning by recruiting dendritic cells and inducing T-cell responses. It is important to consider local versus systemic applications of TLR therapies and the balance between efficacy and inducing TLR tolerance. TLR3 agonists have been shown to be well-tolerated and effective in both directly killing cancer cells and directing immune responses in melanoma. TLRtargeted therapies may be potential treatment options for large or reoccurring skin tumors that may be difficult to treat with surgery or for other skin tumors that are not responsive to current therapies.

\section{ACKNOWLEDGMENTS}

This work was supported by NIH Cancer Prevention and Control Training Grant (R25CA47888) to Erin M. Burns.

\section{REFERENCES}

1. Rogers HW, Weinstock MA, Harris AR, Hinckley MR, Feldman SR, Fleischer AB, et al. Incidence estimate of nonmelanoma skin cancer in the United States, 2006. Arch Dermatol (2010) 146(3):283-7. doi:10.1001/archdermatol.2010.19

2. American Cancer Society. What are the Risk Factors for Basal and Squamous Cell Skin Cancers. (2013). Available from: www.cancer.org/ cancer/skincancer-basalandsquamouscell/ detailedguide/skin-cancer-basal-and-squamouscell-risk-factors

3. Karia PS, Han J, Schmults CD. Cutaneous squamous cell carcinoma: estimated incidence of disease, nodal metastasis, and deaths from disease in the United States, 2012. JAm Acad Dermatol (2013) 68(6):957-66.

4. The Lewin Group. The Burden of Skin Diseases 2005 Prepared for SID and The American Academy of Dermatology Association. (2005). Available from: www.lewin.com/ /media/lewin/site sections/publications/april2005skindisease

5. American Cancer Society. Cancer Facts \& Figures. (2013). Available from: www.cancer.org/acs/ groups/content/@epidemiologysurveilance/ documents/document/acspc-036845.pdf

6. Bensouliah J, Buck P. Skin structure and function. In: Bensouliah J, Buck P, editors. Aromadermatology: Aromatherapy in the Treatment and Care of Common Skin Conditions. Abingdon: Radcliffe Publishing Ltd (2006). p. 1-11.

7. Kupper TS, Fuhlbrigge RC. Immune surveillance in the skin: mechanisms and clinical consequences. Nat Rev Immunol (2004) 4(3):211-22. doi:10. 1038/nri1310

8. Dinulos JG, Mentele L, Fredericks LP, Dale BA, Darmstadt GL. Keratinocyte expression of human beta defensin 2 following bacterial infection: role in cutaneous host defense. Clin Diagn Lab Immunol (2003) 10(1):161-6. doi:10.1128/CDLI.10.1.161166.2003

9. Chung WO, Dale BA. Innate immune response of oral and foreskin keratinocytes: utilization of different signaling pathways by various bacterial species. Infect Immun (2004) 72(1):352-8. doi:10. 1128/IAI.72.1.352-358.2004

10. Song PI, Park YM, Abraham T, Harten B, Zivony A, Neparidze N, et al. Human keratinocytes express functional CD14 and toll-like receptor 4 . J Invest Dermatol (2002) 119(2):424-32. doi:10.1046/j. 1523-1747.2002.01847.x

11. Kawai K, Shimura H, Minagawa M, Ito A, Tomiyama K, Ito M. Expression of functional Tolllike receptor 2 on human epidermal keratinocytes. J Dermatol Sci (2002) 30(3):185-94. doi:10.1016/ S0923-1811(02)00105-6

12. Baker BS, Ovigne JM, Powles AV, Corcoran S, Fry L. Normal keratinocytes express Toll-like receptors (TLRs) 1, 2 and 5: modulation of TLR expression in chronic plaque psoriasis. $\mathrm{Br} J$ Dermatol (2003) 148(4):670-9. doi:10.1046/j.1365-2133. 2003.05287.x

13. Pivarcsi A, Bodai L, Rethi B, Kenderessy-Szabo A, Koreck A, Szell M, et al. Expression and function of Toll-like receptors 2 and 4 in human keratinocytes. Int Immunol (2003) 15(6):721-30. doi:10.1093/intimm/dxg068

14. Lebre MC, van der Aar AM, van Baarsen L, van Capel TM, Schuitemaker JH, Kapsenberg ML, et al. Human keratinocytes express functional Toll-like receptor $3,4,5$, and 9. J Invest Dermatol (2007) 127(2):331-41. doi:10.1038/sj. jid. 5700530

15. Jin SH, Kang HY. Activation of Toll-like Receptors $1,2,4,5$, and 7 on Human melanocytes modulate pigmentation. Ann Dermatol (2010) 22(4):486-9. doi:10.5021/ad.2010.22.4.486

16. Akira S, Hemmi H. Recognition of pathogenassociated molecular patterns by TLR family. Immunol Lett (2003) 85(2):85-95. doi:10.1016/ S0165-2478(02)00228-6

17. Wagner H. The immunobiology of the TLR9 subfamily. Trends Immunol (2004) 25(7):381-6. doi: 10.1016/j.it.2004.04.011

18. Takeda K, Kaisho T, Akira S. Toll-like receptors. Annu Rev Immunol (2003) 21:335-76. doi:10. 1146/annurev.immunol.21.120601.141126

19. Medzhitov R. Toll-like receptors and innate immunity. Nat Rev Immunol (2001) 1(2):135-45. doi:10. 1038/35100529

20. Medzhitov R, Janeway C Jr. Innate immunity. $N$ Engl J Med (2000) 343(5):338-44. doi:10.1056/ NEJM200008033430506
21. Iwasaki A, Medzhitov R. Toll-like receptor control of the adaptive immune responses. Nat Immunol (2004) 5(10):987-95. doi:10.1038/ni1112

22. Akira S, Takeda K, Kaisho T. Toll-like receptors: critical proteins linking innate and acquired immunity. Nat Immunol (2001) 2(8):675-80. doi: 10.1038/90609

23. Kang HY, Park TJ, Jin SH. Imiquimod, a Toll-like receptor 7 agonist, inhibits melanogenesis and proliferation of human melanocytes. J Invest Dermatol (2009) 129(1):243-6. doi:10.1038/jid.2008.184

24. Bianchi ME. DAMPs, PAMPs and alarmins: all we need to know about danger. J Leukoc Biol (2007) 81(1):1-5. doi:10.1189/jlb.0306164

25. Yu L, Wang L, Chen S. Endogenous toll-like receptor ligands and their biological significance. J Cell Mol Med (2010) 14(11):2592-603. doi:10.1111/j. 1582-4934.2010.01127.x

26. Lotze MT, Zeh HJ, Rubartelli A, Sparvero LJ, Amoscato AA, Washburn NR, et al. The grateful dead: damage-associated molecular pattern molecules and reduction/oxidation regulate immunity. Immunol Rev (2007) 220:60-81. doi:10.1111/ j.1600-065X.2007.00579.x

27. Scaffidi P, Misteli T, Bianchi ME. Release of chromatin protein HMGB1 by necrotic cells triggers inflammation. Nature (2002) 418(6894):191-5. doi:10.1038/nature00858

28. van Beijnum JR, Buurman WA, Griffioen AW. Convergence and amplification of toll-like receptor (TLR) and receptor for advanced glycation end products (RAGE) signaling pathways via high mobility group B1 (HMGB1). Angiogenesis (2008) 11(1):91-9. doi:10.1007/s10456-008-9093-5

29. Akira S, Takeda K. Toll-like receptor signalling. Nat Rev Immunol (2004) 4(7):499-511. doi:10.1038/ nri1391

30. Kawai T, Akira S. TLR signaling. Semin Immunol (2007) 19(1):24-32. doi:10.1016/j.smim.2006.12. 004

31. Karin M, Cao Y, Greten FR, Li ZW. NF-kappaB in cancer: from innocent bystander to major culprit. Nat Rev Cancer (2002) 2(4):301-10. doi:10.1038/ nrc780

32. Coussens LM, Werb Z. Inflammation and cancer. Nature (2002) 420(6917):860-7. doi:10.1038/ nature 01322

33. Robinson SC, Coussens LM. Soluble mediators of inflammation during tumor development. $A d v$ Cancer Res (2005) 93:159-87. doi:10.1016/S0065230X(05)93005-4

34. Sato Y, Goto Y, Narita N, Hoon DS. Cancer cells expressing Toll-like receptors and the tumor microenvironment. Cancer Microenviron (2009) 2(Suppl 1):205-14. doi:10.1007/s12307009-0022-y

35. Wu J, Guan M, Wong PF, Yu H, Dong J, Xu J. Icariside II potentiates paclitaxel-induced apoptosis in human melanoma A375 cells by inhibiting TLR4 signaling pathway. Food Chem Toxicol (2012) 50(9):3019-24. doi:10.1016/j.fct.2012.06.027

36. Goto Y, Arigami T, Kitago M, Nguyen SL, Narita $\mathrm{N}$, Ferrone $\mathrm{S}$, et al. Activation of Toll-like receptors 2, 3, and 4 on human melanoma cells induces inflammatory factors. Mol Cancer Ther (2008) 7(11):3642-53. doi:10.1158/1535-7163.MCT-080582

37. Saint-Jean M, Knol AC, Nguyen JM, Khammari A, Dreno B. TLR expression in human melanoma 
cells. Eur J Dermatol (2011) 21(6):899-905. doi:10. 1684/ejd.2011.1526

38. Salaun B, Lebecque S, Matikainen S, Rimoldi D, Romero P. Toll-like receptor 3 expressed by melanoma cells as a target for therapy? Clin Cancer Res (2007) 13(15 Pt 1):4565-74. doi:10.1158/ 1078-0432.CCR-07-0274

39. Mittal D, Saccheri F, Venereau E, Pusterla T, Bianchi ME, Rescigno M. TLR4-mediated skin carcinogenesis is dependent on immune and radioresistant cells. EMBO J (2010) 29(13):2242-52. doi:10. 1038/emboj.2010.94

40. Di JM, Pang J, Sun QP, Zhang Y, Fang YQ, Liu $\mathrm{XP}$, et al. Toll-like receptor 9 agonists up-regulates the expression of cyclooxygenase-2 via activation of NF-kappaB in prostate cancer cells. Mol Biol Rep (2010) 37(4):1849-55. doi:10.1007/s11033009-9620-5

41. Ren T, Wen ZK, Liu ZM, Liang YJ, Guo ZL, Xu L. Functional expression of TLR9 is associated to the metastatic potential of human lung cancer cell: functional active role of TLR9 on tumor metastasis. Cancer Biol Ther (2007) 6(11):1704-9. doi:10.4161/cbt.6.11.4826

42. Di JM, Pang J, Pu XY, Zhang Y, Liu XP, Fang YQ, et al. Toll-like receptor 9 agonists promote IL-8 and TGF-betal production via activation of nuclear factor kappaB in PC-3 cells. Cancer Genet Cytogenet (2009) 192(2):60-7. doi:10.1016/ j.cancergencyto.2009.03.006

43. Chuang HC, Huang CC, Chien CY, Chuang $\mathrm{JH}$. Toll-like receptor 3-mediated tumor invasion in head and neck cancer. Oral Oncol (2012) 48(3):226-32. doi:10.1016/j.oraloncology. 2011.10.008

44. Huang B, Zhao J, Li H, He KL, Chen Y, Chen $\mathrm{SH}$, et al. Toll-like receptors on tumor cells facilitate evasion of immune surveillance. Cancer Res (2005) 65(12):5009-14. doi:10.1158/0008-5472. CAN-05-0784

45. Curtin JF, Liu N, Candolfi M, Xiong W, Assi $\mathrm{H}$, Yagiz K, et al. HMGB1 mediates endogenous TLR2 activation and brain tumor regression. PLoS Med (2009) 6(1):e10. doi:10.1371/journal.pmed. 1000010

46. Salem ML, Kadima AN, Cole DJ, Gillanders WE. Defining the antigen-specific T-cell response to vaccination and poly(I:C)/TLR3 signaling: evidence of enhanced primary and memory CD8 T-cell responses and antitumor immunity. J Immunother (2005) 28(3):220-8. doi:10.1097/01. cji.0000156828.75196.0d

47. Agrawal S, Agrawal A, Doughty B, Gerwitz A, Blenis J, Van Dyke T, et al. Cutting edge: different Toll-like receptor agonists instruct dendritic cells to induce distinct Th responses via differential modulation of extracellular signal-regulated kinase-mitogenactivated protein kinase and c-Fos. J Immunol (2003) 171(10):4984-9.

48. Bianchi L, Campione E, Marulli GC, Costanzo A, Chimenti S. Actinic keratosis treated with an immune response modifier: a case report of six patients. Clin Exp Dermatol (2003) 28(Suppl 1):39-41. doi:10.1046/j.1365-2230.28.s1.13.x
49. Bianchi L, Costanzo A, Campione E, Nistico S, Chimenti S. Superficial and nodular basal cell carcinomas treated with an immune response modifier: a report of seven patients. Clin Exp Dermatol (2003) 28(Suppl 1):24-6. doi:10.1046/j.1365-2230.28.s1. 13. $\mathrm{x}$

50. Chen K, Shumack S. Treatment of Bowen's disease using a cycle regimen of imiquimod $5 \%$ cream. Clin Exp Dermatol (2003) 28(Suppl 1):10-2. doi: 10.1046/j.1365-2230.28.s1.4.x

51. Giannotti B, Vanzi L, Difonzo EM, Pimpinelli N. The treatment of basal cell carcinomas in a patient with xeroderma pigmentosum with a combination of imiquimod $5 \%$ cream and oral acitretin. Clin Exp Dermatol (2003) 28(Suppl 1):33-5. doi: 10.1046/j.1365-2230.28.s1.11.x

52. Naylor MF, Crowson N, Kuwahara R, Teague K, Garcia C, Mackinnis C, et al. Treatment of lentigo maligna with topical imiquimod. $\mathrm{Br} J$ Dermato (2003) 149(Suppl 66):66-70. doi:10.1046/j.0366077X.2003.05637.x

53. Stockfleth E, Trefzer U, Garcia-Bartels C, Wegner T, Schmook T, Sterry W. The use of Toll-like receptor7 agonist in the treatment of basal cell carcinoma: an overview. Br J Dermatol (2003) 149(Suppl 66):53-6. doi:10.1046/j.0366-077X.2003.05626.x

54. Hemmi H, Kaisho T, Takeuchi O, Sato S, Sanjo H, Hoshino K, et al. Small anti-viral compounds activate immune cells via the TLR7 MyD88dependent signaling pathway. Nat Immunol (2002) 3(2):196-200. doi:10.1038/ni758

55. Gupta AK, Cherman AM, Tyring SK. Viral and nonviral uses of imiquimod: a review. JCutan Med Surg (2004) 8(5):338-52. doi:10.1007/s10227005-0023-5

56. Schon MP, Schon M. Immune modulation and apoptosis induction: two sides of the antitumoral activity of imiquimod. Apoptosis (2004) 9(3):291-8. doi: 10.1023/B:APPT. $0000025805.55340 . c 3$

57. Geisse JK, Rich P, Pandya A, Gross K, Andres K, Ginkel A, et al. Imiquimod 5\% cream for the treatment of superficial basal cell carcinoma: a doubleblind, randomized, vehicle-controlled study. J Am Acad Dermatol (2002) 47(3):390-8. doi:10.1067/ mjd.2002.126215

58. Kaporis HG, Guttman-Yassky E, Lowes MA, Haider AS, Fuentes-Duculan J, Darabi K, et al. Human basal cell carcinoma is associated with Foxp3+ T cells in a Th2 dominant microenvironment. J Invest Dermatol (2007) 127(10):2391-8. doi:10.1038/sj.jid.5700884

59. Yokogawa M, Takaishi M, Nakajima K, Kamijima R, Digiovanni J, Sano S. Imiquimod attenuates the growth of UVB-induced SCC in mice through Th1/Th17 cells. Mol Carcinog (2013) 52(10):760-9. doi:10.1002/mc.21901

60. Dummer R, Urosevic M, Kempf W, Hoek K, Hafner J, Burg G. Imiquimod in basal cell carcinoma: how does it work? $\mathrm{Br} J$ Dermato (2003) 149(Suppl 66):57-8. doi:10.1046/j.0366077X.2003.05630.x

61. Meyer T, Surber C, French LE, Stockfleth E Resiquimod, a topical drug for viral skin lesions and skin cancer. Expert Opin Investig Drugs (2013) 22(1):149-59. doi:10.1517/13543784.2013.749236

62. Wang J, Kobayashi M, Han M, Choi S, Takano M, Hashino S, et al. MyD88 is involved in the signalling pathway for Taxol-induced apoptosis and TNF-alpha expression in human myelomonocytic cells. Br J Haematol (2002) 118(2):638-45. doi:10.1046/j.1365-2141.2002.03645.x

63. Krieg AM. Antitumor applications of stimulating toll-like receptor 9 with CpG oligodeoxynucleotides. Curr Oncol Rep (2004) 6(2):88-95. doi: 10.1007/s11912-004-0019-0

64. Hofmann MA, Kors C, Audring H, Walden P, Sterry W, Trefzer U. Phase 1 evaluation of intralesionally injected TLR9-agonist PF-3512676 in patients with basal cell carcinoma or metastatic melanoma. I Immunother (2008) 31(5):520-7. doi:10.1097/ CJI.0b013e318174a $4 \mathrm{df}$

65. Garcia-Zuazaga J, Olbricht SM. Cutaneous squamous cell carcinoma. Adv Dermatol (2008) 24:33-57. doi:10.1016/j.yadr.2008.09.007

66. Eiro N, Ovies C, Fernandez-Garcia B, AlvarezCuesta CC, Gonzalez L, Gonzalez LO, et al. Expression of TLR3, 4, 7 and 9 in cutaneous malignant melanoma: relationship with clinicopathological characteristics and prognosis. Arch Dermatol Res (2013) 305(1):59-67. doi:10.1007/s00403012-1300-y

67. Broad A, Kirby JA, Jones DE, Applied I, Transplantation Research G. Toll-like receptor interactions: tolerance of MyD88dependent cytokines but enhancement of MyD88-independent interferon-beta production. Immunology (2007) 120(1):103-11. doi:10.1111/j.1365-2567.2006.02485.x

68. de Vos AF, Pater JM, van den Pangaart PS, de Kruif MD, van't Veer C, van der Poll T. In vivo lipopolysaccharide exposure of human blood leukocytes induces cross-tolerance to multiple TLR ligands. J Immunol (2009) 183(1):533-42. doi:10.4049/jimmunol.0802189

69. Bourquin C, Hotz C, Noerenberg D, Voelkl A, Heidegger S, Roetzer LC, et al. Systemic cancer therapy with a small molecule agonist of tolllike receptor 7 can be improved by circumventing TLR tolerance. Cancer Res (2011) 71(15):5123-33. doi:10.1158/0008-5472.CAN-10-3903

Received: 10 January 2014; accepted: 17 March 2014; published online: 31 March 2014.

Citation: Burns EM and Yusuf N (2014) Toll-like receptors and skin cancer. Front. Immunol. 5:135. doi: 10.3389/fimmu.2014.00135

This article was submitted to Immunological Tolerance, a section of the journal Frontiers in Immunology. Copyright () 2014 Burns and Yusuf. This is an openaccess article distributed under the terms of the Creative Commons Attribution License (CC BY). The use, distribution or reproduction in other forums is permitted, provided the original author(s) or licensor are credited and that the original publication in this journal is cited, in accordance with accepted academic practice. No use, distribution or reproduction is permitted which does not comply with these terms. 